\title{
ANTIBACTERIAL AND ANTIFUNGAL ACTIVITY OF HERBAL MEDICINE CONTAINING ALUM AS MEDICINE PREPARATION FOR VAGINAL DISCHARGE
}

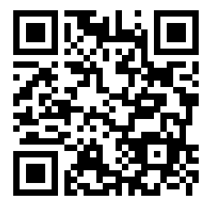

\author{
Finna Ashfia ${ }^{1}$, Titik Taufikurohmah ${ }^{*}{ }^{\square}$, Suyatno ${ }^{1}$, Eka Apriyosa ${ }^{2}$ \\ ${ }^{* 1}$ Department of Chemistry, Faculty of Mathematic and Natural Science, Universitas Negeri \\ Surabaya, Indonesia \\ 2 PT. Khanza Ekselensia Utama, Indonesia
}

DOI: https://doi.org/10.29121/granthaalayah.v8.i6.2020.460

Article Type: Research Article

Article Citation: Finna Ashfia, Titik Taufikurohmah, Suyatno, and Eka Apriyosa. (2020). ANTIBACTERIAL AND ANTIFUNGAL ACTIVITY OF HERBAL MEDICINE CONTAINING ALUM AS MEDICINE PREPARATION FOR VAGINAL DISCHARGE. International Journal of Research GRANTHAALAYAH, 8(6), 169-178. https://doi.org/10.29121/granthaa layah.v8.i6.2020.460

Received Date: 10 May 2020

Accepted Date: 28 June 2020

Keywords:

Herbal Medicine

Antibacterial

Neisseria Gonorrhoeae

Antifungal

Candida Albicans

Vaginal Discharge

\section{ABSTRACT}

Background: Vaginal discharge can caused by bacteria and fungi. Vaginal discharge treatment can be done through the use of herbal medicines that has lower side effects compared to synthetic drug. The ' $\mathrm{X}$ ' alum herbal medicine used in this research containing majakani, betel leaf, henna leaf, gambier, turmeric, and alum. The research aims to determine the antibacterial and antifungal activities of alum herbal medicine against Neisseria gonorrhoeae and Candida albicans.

Method: The methode used was disk diffusion.

Results: Antibacterial testing was constrained by the presence of inhomogeneous samples and the separation of alum from the solvent used, so the data obtained was considered to be less valid. While the antifungal test has the largest inhibition zone of $11.98 \mathrm{~mm}$ at concentration of $50 \%$. Expansion of the concentration is carried out to determine the inhibitory zone in the actual use of herbal medicine expressed in $100 \%$ concentration. The results of inhibition zone diameter of $100 \%$ was $15.6623 \mathrm{~mm}$. This result show that at $100 \%$ this herbal medicine has almost the same activity as the synthetic drug which is quite effective in inhibiting the growth of fungi.

Conclusions: This research provided that herbal medicine has antifungal activity that almost effective as Ketoconazole.

\section{INTRODUCTION}

Reproductive health is one of the health problems that are often experienced by women. Reproductive health disorders are often caused by bacterial or fungal infections due to bad personal hygiene such as laziness to maintain the cleanliness of the reproductive organs. One of the problems of women's reproductive health is vaginal discharge. Based on previous research, it was stated that $75 \%$ of women in the world have experienced vaginal discharge, whereas in Indonesia 50\% of women experience vaginal discharge and continue to increase each year until it reaches $70 \%[1]$ 
Vaginal discharge (fluor albus/ leucorrhea) is a symptom of reproductive organ disorders in the form of discharge from the vaginal reproductive organs in addition to menstrual blood [2]. Vaginal discharge can be classified as normal or physiological vaginal discharge and abnormal or pathological vaginal discharge [3]. Normal (physiological) vaginal discharge is a discharge from the vagina in a normal state that is influenced by hormones, limpid, thin, odourless, and not itchy, whereas abnormal vaginal discharge (pathological) is characterized by a lot of fluid that comes out of the vagina, yellowish-white/yellow, smell bad, and accompanied by itching [2]. Pathological vaginal discharge generally causes many complaints such as itching, burning, pain during sexual intercourse (dyspareunia) or when urinating (dysuria), and redness [3].

Pathological vaginal discharge is caused by bacteria, such as bacterium Neisseria gonorrhoeae. Neisseria gonorrhoeae is a gram-negative bacterium that causes gonorrhea. This bacterial infection can be caused by a transmission that occurs through sexual contact with gonorrhea sufferers. Based on case studied before found that patients diagnosed with gonorrhea have symptoms such as discharge from the vagina that is thick, yellow, and painful when urinating. This diagnosis is supported by the results of laboratory tests that show positive results of gonorrhea [4]. In the other hand, vaginal discharge also caused due to infection by fungi, such as the Candida albicans. This fungus is one of the normal flora in the mucous membranes of the respiratory tract, digestive tract, and female genital organs. Vaginal discharge caused by fungal infection of Candida albicans is commonly known as candidiasis vaginalis. Candidiasis vaginalis can occur due to the uncontrolled growth of the Candida albicans. Vaginal discharge caused by a fungal infection is accompanied by symptoms such as a discharge of yellowish-white liquid such as milk, unpleasant odour, and accompanied by itching and heat in the genitals [5].

Based on the facts that cause pathological vaginal discharge, pathological vaginal discharge must be treated immediately so as not to cause more serious illness. Vaginal discharge treatment can be done through the use of herbal medicines. Herbal medicines are pharmaceutical preparations that utilize active ingredients from natural ingredients. The use of herbal medicines derived from plants and natural ingredients has both side effects and danger levels lower compared to synthetic drugs [6].

The herbal medicine samples used in this research contains several medicinal plants such as majakani, betel leaf, henna leaf, gambier, turmeric, and alum. Simplicia medicinal plants contained in this herbal medicine have several phytochemical compounds that have antibacterial and/or antifungal abilities. In addition, the presence of alum in this herbal medicine can be used to treat vaginal discharge with astringent properties that can reduce secretions released from the vagina, and alum also has antibacterial and antifungal activity [7]. In its use as a vaginal discharge treatment, these ingredients have some ingredients and benefits that support and synergize with each other. The synergy and mutually beneficial effect on the content of this herbal medicine not only can produce a greater effect than the single effect produced by each active ingredient [8], but it can also reduce the violence of one ingredient. In a similar study, Zaki, et al. (2016) found that consumption of Amla and Alum for Candida vaginitis patient in India, there found that both of Amla and Alum could be effective alternative treatment of Candida vaginitis with no side effects.

Herbal medicine used in this research are herbal medicines that are claimed to treat female problems, one of which is vaginal discharge. However, there is no scientific information about the content of active compounds and their specific properties of this herbal medicine. Therefore this research aims to determine the antibacterial and antifungal activity of herbal medicine containing alum from brand ' $X$ ' against the Neisseria gonorrhoeae bacteria and the Candida albicans fungus.

\section{MATERIALS AND METHODS}

\subsection{MATERIALS}

Herbs medicine containing alum by brand 'X', aquadest, Saburoud Dextrose Broth, Saburoud Dextrose Agar, Thayer-Martin medium, Ciprofloxacin, Ketoconazole, disc paper, Neisseria gonorrhoeae 49226, Candida albicans ATCC 10231. 
Finna Ashfia, Titik Taufikurohmah, Suyatno, and Eka Apriyosa

\subsection{METHODS}

\subsubsection{SAMPLE PREPARATION}

Samples of ' $X$ ' alum herbal medicine products were weighed using an analytical balance of $5 ; 2.5 ; 12.5 ; 0.625$; and 0.313 grams and take 1 pill randomly of 0,169 grams then dissolved with distilled water to form concentrations of $50 \%, 25 \%, 12.5 \%, 6.25 \%, 3.13 \%$, and $1,69 \%(\% \mathrm{~b} / \mathrm{v})$.

\subsubsection{ANTIBACTERIAL TEST}

The antibacterial test of Neisseria gonorrhoeae uses the disk diffusion method with Mueller-Hinton media. First Thayer-Martin media was prepared then poured into a petri dish. Prepared Neisseria gonorrhoeae 49226 bacteria with turbidity of 1 Mc-Farland. Then a bacterial swab is carried out and rubbed evenly over the Thayer-Martin medium on a petri dish. $6 \mathrm{~mm}$ diameter disk paper is soaked in $10 \mu \mathrm{L}$ of sample solution with variations in concentration, positive control (Ciprofloxacin 5 $\mathrm{g}$ ), and negative control (aquadest) for 15 minutes. Then placed on a petri dish and incubated at a temperature of $35^{\circ} \mathrm{C}-37^{\circ} \mathrm{C}$ for 24 hours. Bacterial inhibition zones are characterized by clear areas around the disc on the surface of media, then measured using callipers in millimetres ( $\mathrm{mm}$ ) [9].

\subsubsection{ANTIFUNGAL TEST}

Rejuvenation of pure stock culture of Candida albicans ATCC 10231 done by preparing a sterile Sabouraud Dextrosa Broth liquid media, then adding 1 osse of fungi culture taken from the skewed medium and vortex to make it homogeneous. After that, incubated for 24 hours at $37^{\circ} \mathrm{C}$. Next is the making of specific culture media for Candida albicans fungi. In this case the media used Sabouraud Dextrosa Agar. The media should be poured into a petri dish and swab with rejuvenated fungi culture.

Testing of antifungal activity on herbal medicine was carried out using the disc diffusion method. Where the $6 \mathrm{~mm}$ diameter disc paper is soaked in $10 \mu \mathrm{L}$ sample solution with variations in concentration, positive control (Ketoconazole 2\%), and negative control (aquadest) for 15 minutes. Then placed on a petri dish and incubated at a temperature of $35^{\circ} \mathrm{C}-37^{\circ} \mathrm{C}$ for 48 hours. Fungal inhibition zones are marked with clear areas around the disc on the surface of the agar media, then measured using callipers in millimetres ( $\mathrm{mm}$ ) [10].

\section{RESULTS AND DISCUSSIONS}

\subsection{SAMPLE PREPARATION}

Herbal medicine is a remedy used to cure a disease that comes from plants. The herbal medicine works by giving energy to the part certain body and balance the body's condition so that it helps restore overall body balance. The use of herbal medicines derived from plants and natural ingredients has both side effects and danger levels lower compared to synthetic chemical drugs [6].

In this research, herbal medicine was used in the form of pills. This herbal medicine is claimed to overcome the odour, itching in female area, reduce the mucus in female area, as well as preventing and treating disorders of the female area. Based on a patent that has been filed by a production company, this herbal medicine contains herbal simplicia such as majakani, betel leaf, henna leaf, gambier, turmeric, and alum.

Based on the results of literature studies, simplicia medicinal plants used in herbal medicines contain several phytochemical compounds. The phytochemical screening of majakani plants showed the presence of tannin, saponin, flavonoid, triterpenoid, and alkaloid contents [11]. This herb is also widely used for the treatment of hemorrhoids, vaginal discharge, irregular periods, and others. Betel leaf contains phenol compounds [12], both phenols with catechol nuclei and simple phenols such as eugenol [13], flavonoids, tannins, and saponins [14]. Furthermore henna leaf contain saponin, flavonoid, and tannin compounds which can be used as vaginal discharge treatment and phenols which have antifungal and antibacterial activity [15]. Gambier plants contain phytochemical compounds such as catechins from polyphenols group [16], tannins, and alkaloids. Turmeric contains phytochemical compounds such as curcumin which is a derivative of phenols, flavonoids, tannins, and alkaloids [17]. In the other hand, the 
presence of alum in this herbal medicine have an astringent properties that can reduce secretions released from the vagina and has antibacterial and antifungal activity [7].

The concentrations used in this research are $50 \%, 25 \%, 12.5 \%, 6.25 \%, 3.13 \%$, and 1 pill of ' $\mathrm{X}$ ' alum herbal medicine with 1,69\%. The sample solution used is shown in Figure 1. Based on the results in Figure 1 shows that the higher concentration of ' $X$ ' alum herbal medicine, the color of the solution will be more concentrated. This is because of ' $X$ ' alum herbal medicine used more as well as increase in concentration.
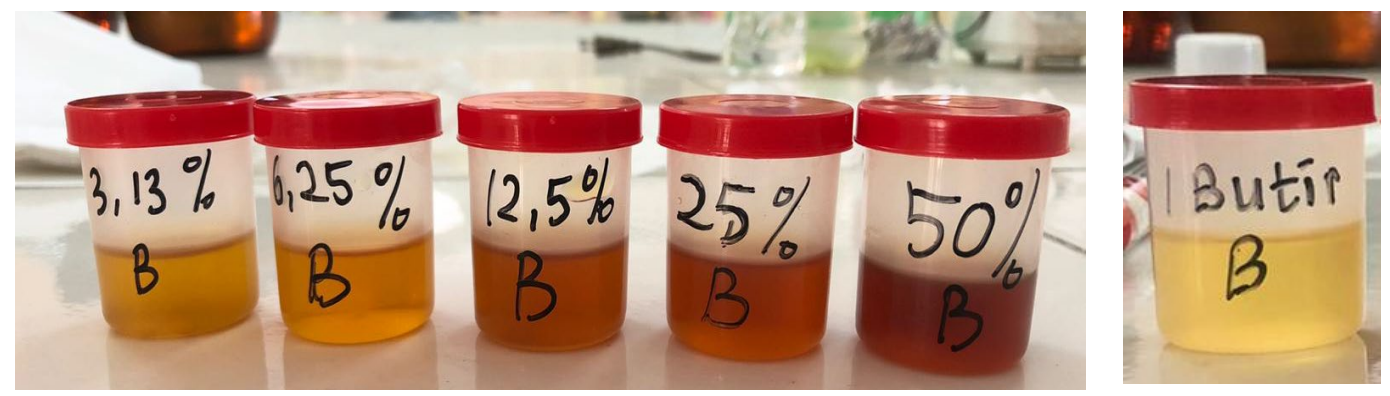

Figure 1: Solution of Herbal Medicine in various concentrations. (a) Variations concentration of ' $X$ ' alum herbal medicinal, (b) ' $\mathrm{X}$ ' alum herbal medicine at concentration 1, 69\% (1 pill).

\subsection{ANTIBACTERIAL ACTIVITY TEST}

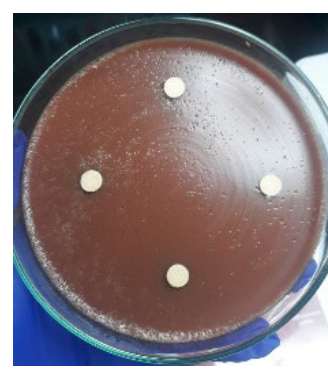

A

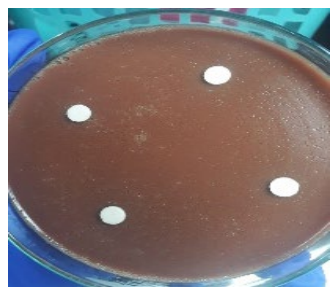

E

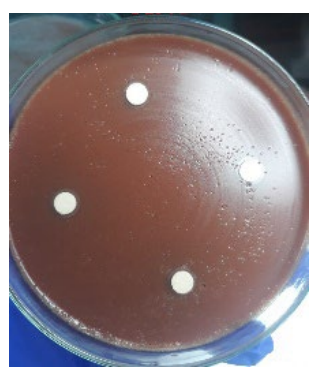

$\mathrm{B}$

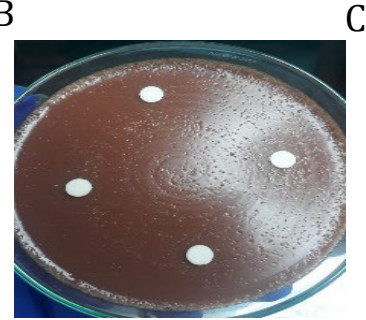

$\mathrm{F}$

C
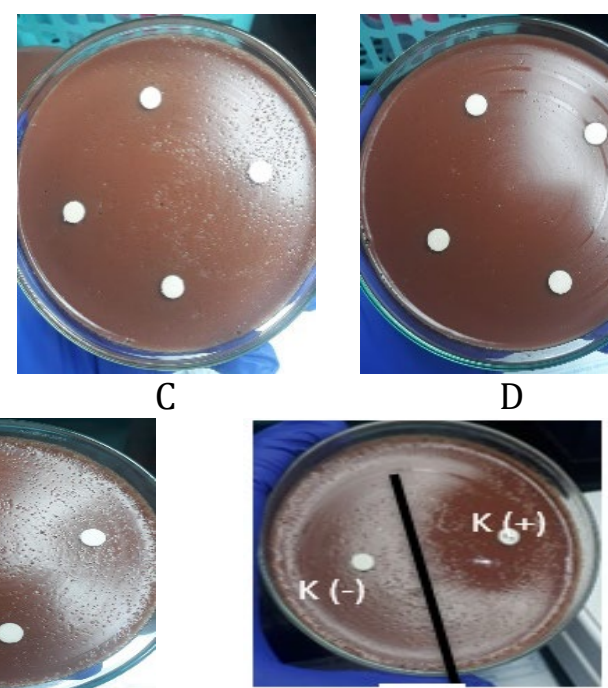

G

Figure 2: Diameter of antibacterial inhibitory zone of ' $X$ ' alum herbal medicine. A. 50\% concentration, B. 25\% concentration, C. 12,5\% concentration, D. 6,25\% concentration, E. 3,125\% concentration, F. 1,69\%\% concentration, G. (+) control Ciprofloxacin $5 \mu$ g and (-) control aquadest.

Table 1: Inhibitory zone diameter test results of antibacterial activity against Bacteria Neisseria gonorrhoeae 49226.

\begin{tabular}{|l|c|c|c|c|c|}
\hline \multirow{2}{*}{ Concentration } & \multicolumn{6}{|c|}{ Inhibitory zone diameter $\pm(\mathrm{mm})$} & \multirow{2}{*}{ Average } \\
\cline { 2 - 5 } & I & II & III & IV & \\
\hline $50 \%$ & - & - & - & - & - \\
\hline $25 \%$ & - & - & - & - & - \\
\hline $12,5 \%$ & - & - & - & - & - \\
\hline $6,25 \%$ & - & - & - & - & - \\
\hline $3,125 \%$ & - & - & - & - & - \\
\hline $1,69 \%(1$ pill) & - & - & - & - & - \\
\hline
\end{tabular}




\begin{tabular}{|l|c|c|c|c|c|}
\hline Positive Control & 47 & 47 & 47 & 47 & 47 \\
\hline Negative Control & - & - & - & & - \\
\hline
\end{tabular}

Notes: - = No/zero inhibition zone; positive control = Ciprofloxacin.

Bacteria Neisseria gonorrhoeae is a gram-negative bacteria that causes gonorrhea. This disease can be transmitted through infected secretions directly from one mucosa to the other mucosa. Transmission generally occurs by physical contact, especially through sexual intercourse carried out genito-genital, oro-genital, or anogenital [18]. Gonorrhea in women with symptomatic begins with discharge from the vagina (vaginal discharge) in the form of thick, yellow liquid, and feels hurt when urinating. If asymptomatic, it can be more severe and cause serious health problems such as the occurrence of pelvic inflammatory disease (Pelvic Infectious Diseases), ectopic pregnancy, and infertility. To overcome the occurrence of gonorrhea, an antibacterial compound is needed. Antibacterial compounds are compounds that can kill or inhibit bacterial growth.

The results of antibacterial activity test of the ' $X$ ' alum herbal medicine against bacterium Neisseria gonorrhoeae 49226 are shown in Table 1. It can be stated that there is no inhibitory zone in each concentrations. These results are considered less valid because of the lack of accuracy of researchers when preparing sample which causes inhomogeneous sample solution when will be tested. So, it can reduce the ability of ' $X$ ' alum herbal medicine to inhibit growth of bacterium. Inhomogeneous sample might be due to the alum content in the sample which at low temperatures recrystallizes, so there is separation of alum with the solvent used. Furthermore, the selection of inappropriate concentration, in this case the concentration used is too low, it can also affect the formation of clear zones around the discs. The lower concentration, the less herbal medicine was used so that the possibility of antibacterial potential compounds in the ' $\mathrm{X}$ ' alum herbal medicine is too slight and not enough to inhibit the growth of Neisseria gonorrhoeae [19].

Besides the various concentration of ' $\mathrm{X}$ ' alum herbal medicine, this research also used negative control and positive control. Where the negative control used is aquadest and the positive control used is Ciprofloxacin $5 \mu \mathrm{g}$. The results of the antibacterial test on the negative control did not show the inhibitory zone because they didn't have antibacterial compounds so it was unable to inhibit the growth of Neisseria gonorrhoeae. While the antibacterial test results on positive control showed that the diameter of the inhibitory zone formed was $47 \mathrm{~mm}$. Ciprofloxacin is a broad-spectrum fluoroquinolin antibiotic against gram-positive and gram-negative bacteria. The selection of ciprofloxacin as a positive control because this antibiotic has a broad antimicrobial effect and microbial resistance that does not rapidly develop [20]. The antibacterial effect of ciprofloxacin is caused by disruption of the enzyme DNA topoisomerase needed for bacterial DNA synthesis [21].

\subsection{ANTIFUNGAL ACTIVITY TEST}

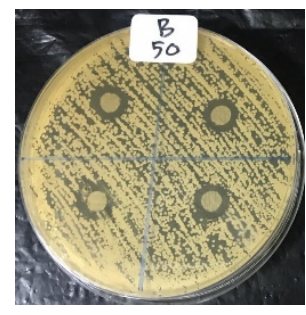

A

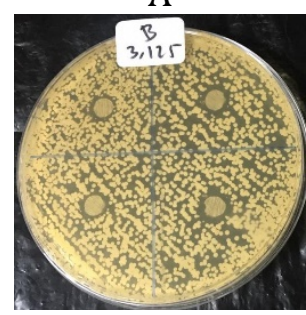

E

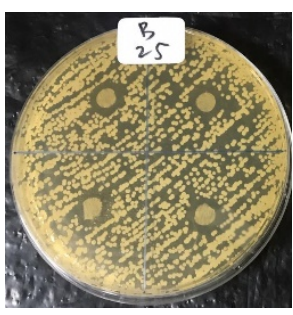

B

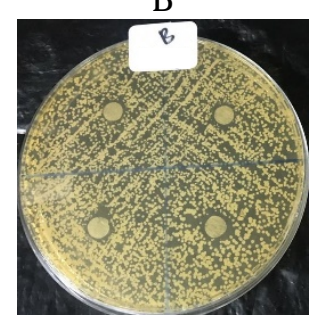

$\mathrm{F}$

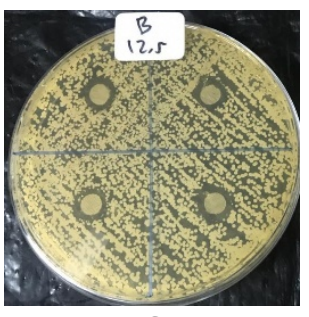

C

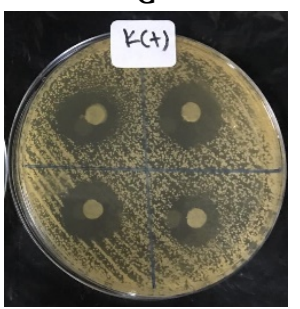

G

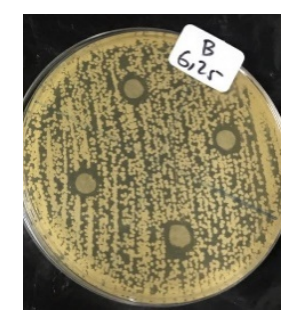

D

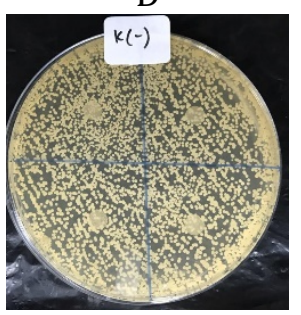

$\mathrm{H}$

Figure 3: Inhibitory zone diametes of ' $\mathrm{X}$ ' alum herbal medicine. A. 50\% concentration, B. 25\% concentration, $\mathrm{C}$. $12,5 \%$ concentration, D. 6,25\% concentration, E. 3,125\% concentration, F. 1,69\% concentration, G. (+) control

Ketoconazole 2\%, H. (-) control aquadest. 
Antibacterial and Antifungal Activity of Herbal Medicine Containing Alum as Medicine Preparation for Vaginal Discharge

Table 2: Inhibition zone diameters of antifungal activity test results of the Candida albicans ATCC 10231.

\begin{tabular}{|l|c|c|c|c|c|}
\hline \multirow{2}{*}{ Concentration } & \multicolumn{4}{|c|}{ Inhibitory zone diameter $\pm(\mathrm{mm})$} & \multirow{2}{*}{ Average } \\
\cline { 2 - 5 } & I & II & III & IV & \\
\hline $50 \%$ & 12,30 & 12,25 & 11,75 & 11,65 & 11,98 \\
\hline $25 \%$ & 11,95 & 11,85 & 11,55 & 10,9 & 11,56 \\
\hline $12,5 \%$ & 11,55 & 11,20 & 10,90 & 10,5 & 11,03 \\
\hline $6,25 \%$ & 10,75 & 10,45 & 10,05 & 9,85 & 10,27 \\
\hline $3,125 \%$ & 9,90 & 9,50 & 9,10 & 9,15 & 9,41 \\
\hline $1,69 \%(1$ pill) & 8,95 & - & 7,65 & 7,95 & 8,18 \\
\hline Positive Control & 17,95 & 15,65 & 16,30 & 16,25 & 16,53 \\
\hline Negative Control & - & - & - & & - \\
\hline
\end{tabular}

Notes: - = No/zero inhibition zone; positive control = ketoconazole.

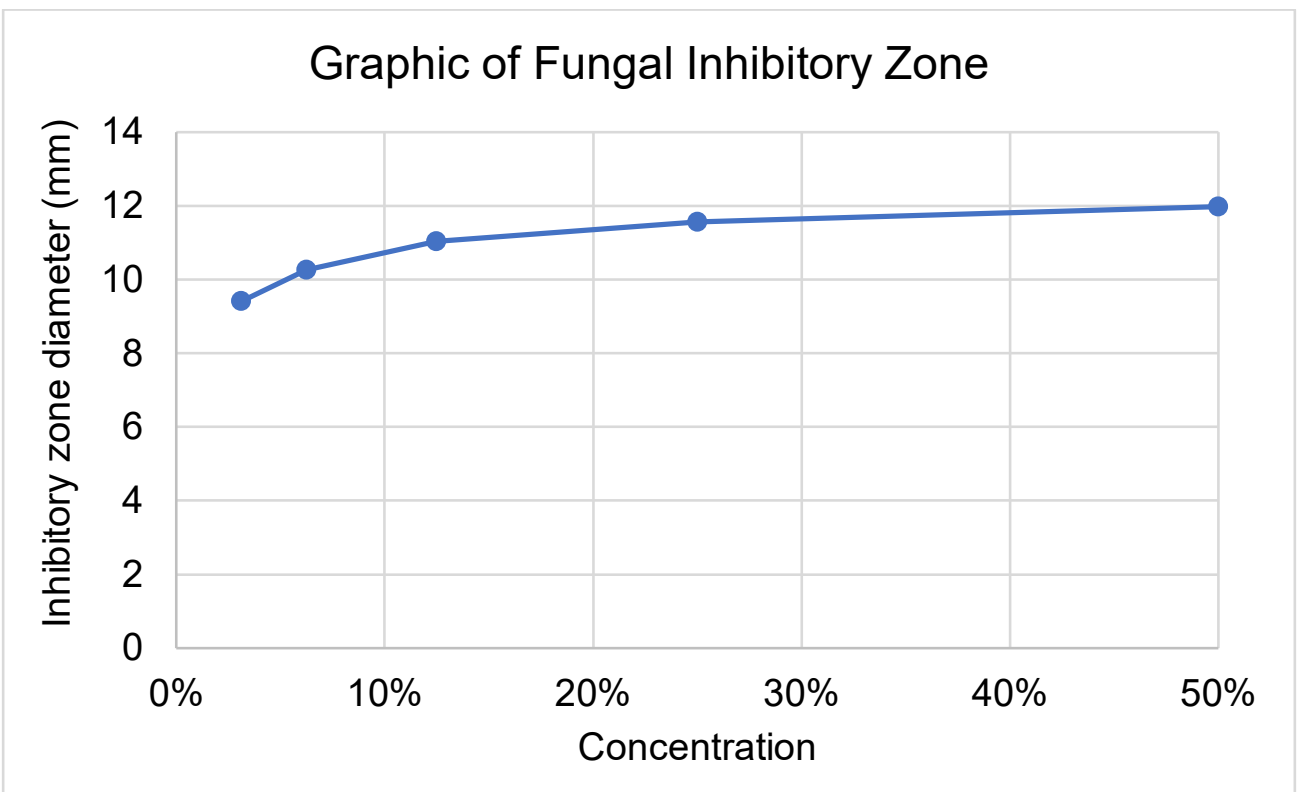

Figure 4: Graphic of inhibitory zone diameter Candida albicans at various concentration of 'X' alum herbal medicine.

Candida albicans is actually a normal flora fungus that is commonly found in the vagina. However, if the growth is in excessive amounts and is not normal then this fungus can cause candidiasis disorders [22]. The overgrowth of the Candida albicans fungus in the vagina can be caused by changes in vaginal activity or hormonal imbalance. Candidiasis is indicated by the presence of vaginal discharge, which is a yellowish-white discharge such as milk, odourless, and accompanied by itching in the vagina [5].

To treat candidiasis disorders, antifungal compounds is needed. Antifungal compounds have mechanism of action by inhibiting the action of enzymes, damaging the fungal cell membrane, inhibiting the fungal enzyme system so that it interferes with the formation of hyphae, affects the synthesis of nucleic acids and proteins, and causes damage to cell walls [11]. Damage to one site can cause changes to the death of the cell [23]. Antifungal compound testing was carried out to determine the ability of sample to inhibit the growth of fungi, especially the Candida albicans.

The results of antifungal activity tests on ' $\mathrm{X}$ ' herbal medicine against Candida albicans ATCC 10231 is show on Figure 3 and Table 2. In Figure 3 show the clear zone around paper disc. It is stated to inhibitory zone diameter of ' $\mathrm{X}$ ' alum herbal medicine. Table 2 show the diameter of inhibition zone in each concentration. The existence of inhibitory zones in each variation suspected due to the presence of several active compounds in medicinal plant simplicia such as alkaloids, flavonoids, phenols, steroids, tannins, and the presence of alum which has the ability to inhibit the growth of fungi [7]. 
Active compounds of secondary metabolites that can act as antifungals such as alkaloids which work by inhibiting esterase and DNA and RNA polymerase and inhibiting cell respiration. Flavonoids that work by denaturing proteins, causing interference in cell formation. Saponins which can inhibit fungi by decreasing the surface tension of the cell wall so that the permeability increases [11]. Increased cell permeability causes intracellular fluid that is more concentrated the child is pulled out so that nutrients, metabolism substances, enzymes, proteins in the cells out and fungi will die. Phenol has antifungal activity because it has a hydroxy group that can bind to the sulfhydryl group of fungal proteins so that it can change the confirmation of the target cell membrane protein and disturb the growth of fungal cells [11]. Steroids can inhibit fungal growth by interfering with the growth and development of fungal spores [24]. Tannin compounds can inhibit the growth of fungi with its ability to inhibit the synthesis of chitin which is used in the formation of cell walls in fungi and damage cell membranes [25]. Whereas alum can inhibit the growth of fungi with its astringent properties which causes the unwillingness of fungal growth media.

Based on the content of several active compounds in medicinal plants and alum in herbal medicine samples and the results of antifungal tests show that ' $X$ ' alum herbal medicine has ability to inhibit the growth of Candida albicans. At concentration of $50 \%$ the diameter of the inhibition zone formed was $11.98 \mathrm{~mm}$, at concentration of $25 \%$ the diameter formed was $11.56 \mathrm{~mm}$, at concentration of $12.5 \%$ the diameter formed was $11.03 \mathrm{~mm}$, at concentration of $6.25 \%$ the diameter formed was $10.27 \mathrm{~mm}$, at concentration of $3.125 \%$ the diameter which formed was $9.41 \mathrm{~mm}$, and at $1,69 \%$ or 1 pill of ' $X$ ' alum herbal medicine the diameter formed was $8.18 \mathrm{~mm}$. The ability of this ' $\mathrm{X}$ ' alum herbal medicine is able to inhibit the growth of Candida albicans, but does not eliminate the entire population. Candida albicans is a fungus normal flora that play a role in the balance of microorganisms in the vagina [26]. If overgrowth can cause vaginal discharge and when the population in the vagina has disappeared it can cause pathogenic bacteria easily growth. The use of ' $\mathrm{X}$ ' herbal medicine regularly is thought to be able to treat vaginal discharge slowly.

In Figure 4, it can be seen that the higher concentration, the greater diameter of the inhibition zone formed. The higher concentration, the more ' $\mathrm{X}$ ' alum herbal medicine used. So, the possibility of an active compound in it is higher and the antifungal activity will be even greater. These results are consistent with the statement of Pelczar and Chan [23] that the higher concentration of an antimicrobial compound, the more microbes are killed or stunted in growth so that the greater antimicrobial activity.

An antifungal test with a negative control and a positive control was carried out. In negative control using distilled water, the diameter of the inhibition zone is not formed. This is due to the fact that aquadest do not contain antifungal active compounds [11]. Whereas on positive control using $2 \%$ ketoconazole solution formed inhibition zone diameter with an average of $16.53 \mathrm{~mm}$. Ketoconazole is an imidazole-derived antifungal drug that has antifungal activity against dermatophytes, yeasts, such as Candida albicans. Ketoconazole are the best azole group in inhibiting the growth of the Candida albicans. Ketoconazole works as an antifungal by inhibiting the growth of cytochrome enzymes that are necessary for the synthesis of ergosterol which is needed to maintain the integrity of the fungal cell membrane. If ergosterol has decreased, it can affect the permeability of fungal cell membranes [27]. In addition, ketoconazole can inhibit fungal growth by stimulating phagocytosis and inhibiting the growth of the filament in the fungus Candida albicans. The main side of ketoconazole can disrupt the respiration of Candida albicans by inhibiting the activity of NADH Oxidase which results in damage to the fungal cell membrane [28].

Aside from determining concentration variations that have been determined in this research, the fact is this ' $\mathrm{X}$ ' alum herbal medicine consumed in its original form then assumed to be $100 \%$ concentration which is without dilution, whereas in this research it was limited to $50 \%$ concentration. So, to be able to represent the real activities in the use of ' $\mathrm{X}$ ' alum herbal medicine, we need to determine the diameter of the inhibition zone on $100 \%$ ' $\mathrm{X}$ ' alum herbal medicine with the extension of the slope in Figure 5. 


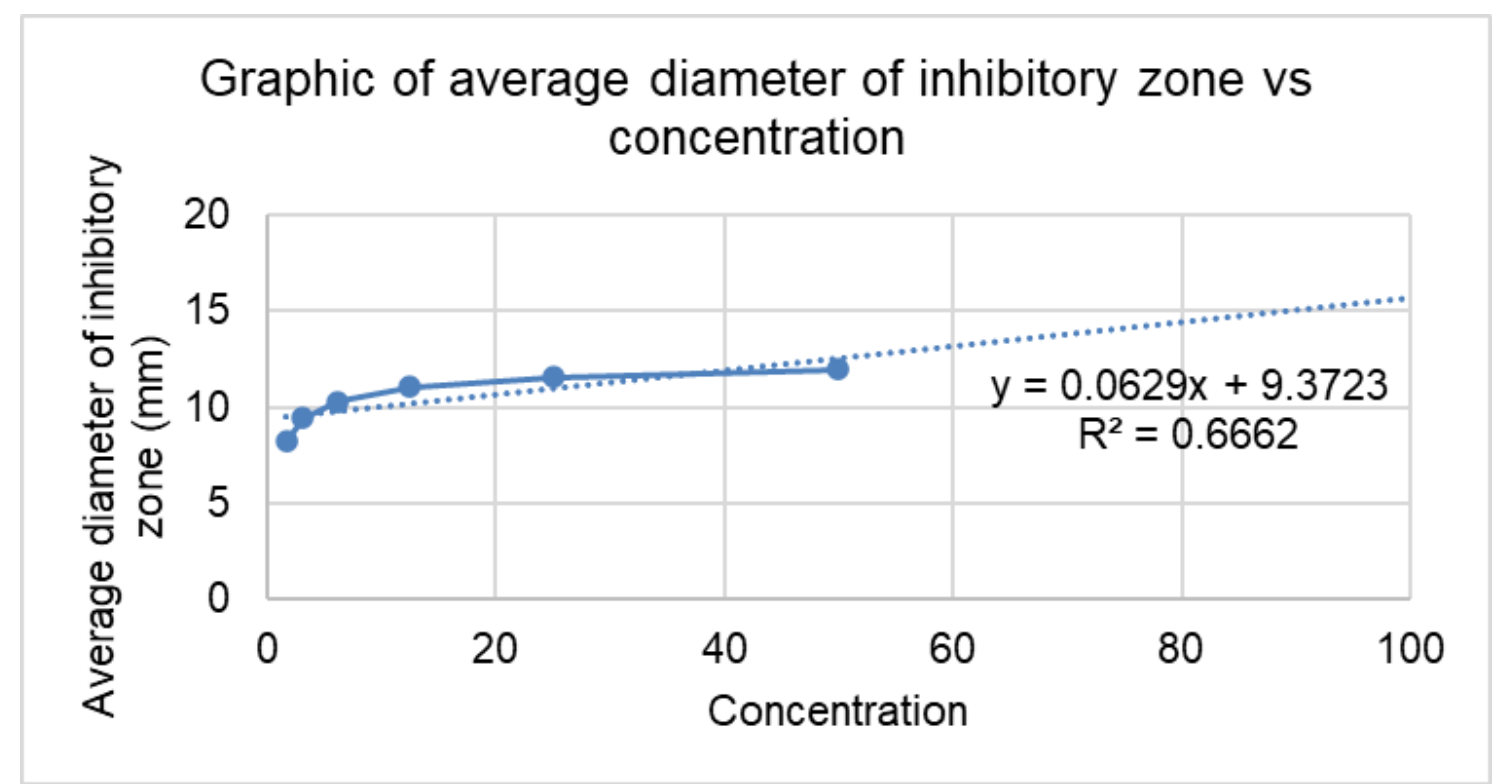

Figure 5: Graphic of average diameter of inhibitory zone vs. concentration with trend line up to $100 \%$ ' $X$ ' alum herbal medicine.

In figure 5 show the trend line from the graph shows the increase in diameter of the inhibitory zone along with the increase in concentration. From the data in table 2, a graph was made between the concentration vs. the average diameter of the inhibition zone as shown in figure 4 so the equation $y=0,0629 x+9.3723$ is obtained. Those equation can be used to determine the average diameter of the inhibitory zone of fungi in $100 \%$ of the ' $\mathrm{X}$ ' alum herbal medicine by replacing the variable $\mathrm{x}$ with the 100 .

$$
\begin{gathered}
y=0,0629 x+9,3723 \\
x=100, \text { so } \rightarrow y=0,0629 \times 100+9,3723 \\
y=6,29+9,3723 \\
y=15,6623
\end{gathered}
$$

So the average value of the diameter of the inhibitory zone in $100 \%$ ' $\mathrm{X}$ ' alum herbal medicine is $15,6623 \mathrm{~mm}$. Compared with the synthetic drug 'Ketoconazole' as positive control which has a inhibition zone of $16.53 \mathrm{~mm}$, the diameter of inhibitory zone in $100 \%$ of ' $X$ ' alum herbal medicine has not much different. Inhibitory zone diameter of $15.6623 \mathrm{~mm}$ on the use of $100 \%$ of herbal medicinal was quite effective to inhibit the growth of the fungus Candida albicans, this is a good result where the herbal medicine used has almost the same activity as the synthetic drug 'ketoconazole' in inhibiting the growth of fungi Candida albicans. And if it look from of side effects, ketoconazole might cause some side effects such as nausea and vomiting [29], while ' $X$ ' alum herbal medicine which consisting of several medicinal plants and alum will be safer to use because it has an lower side effects.

\section{CONCLUSIONS AND RECOMMENDATIONS}

There is an obstacle while doing antibacterial testing caused by inhomogeneous sample so the data has been obtained is less valid. Meanwhile, antifungal testing shows that the ' $\mathrm{X}$ ' alum herbal medicine has antifungal activities which is almost effective as the synthetic drug 'Ketoconazole'.

\section{SOURCES OF FUNDING}

None.

\section{CONFLICT OF INTEREST}

None. 
Finna Ashfia, Titik Taufikurohmah, Suyatno, and Eka Apriyosa

\section{ACKNOWLEDGMENT}

This project was collaboration with PT Khanza Ekselensia Utama. Therefore, the authors would like to thank to PT Khanza Ekselensia Utama who has funding this project.

\section{REFERENCES}

[1] Pradnyandari Ida Ayu Cintya, I Gede Ngurah H. W. S., and Made Bagus Dwi Aryana. Gambaran pengetahuan, sikap, dan perilaku tentang vaginal hygiene terhadap kejadian keputihan patologis pada siswi kelas 1 di SMA Negeri 1 Denpasar periode Juli 2018. Intisari Sains Medis, 10(1), 2019, 88 - 94.

[2] Kurniawati, C., \& Muji, S. Aplikasi Teori Healt Belief Model Dalam Pencegahan Keputihan Patologi. Jurnal Promkes, 2(2), 2014, 117 - 127.

[3] Rusdi Numlil Khaira, Trisna Yulia, and Soemiati Atiek. Pola Pengobatan Fluor Albus di Rumah Sakit Umum Pusat Nasionall DR CIPTO MANGUNKUSUMO serta Faktor - Faktor yang Mempengaruhinya (Analisis Data Rekam Medik Tahun 2006 - 2007). Majalah Ilmu Kefarmasian, 2008, 5(2).

[4] Amalia Rizqi, Nurunniyah Siti, and Retna Purwanti. Asuhan Kebidanan Gangguan Kesehatan Reproduksi Keputihan dengan Gonore Pada An.K Umr 12 Tahun di Puskesmas Sleman. Naskah Publikasi Universitas Alma Ata Yogayakarta, 2016.

[5] Jessica Priscilla, Widyawati, Armalina Desy. Hubungan Antara Terjadinya Kandidasis Vulvovaginalis dengan Penggunaan Kontrasepsi Hormonal. Jurnal Kedokteran Diponegoro, 5(4), 2016.

[6] Himalaya, D. Pengaruh Pemberian Ekstrak Biji Manjakani (Quercus infectoria Gall) Terhadap Bakteri Vaginosis dan Candida Penyebab Keputihan (Leukorrhea). Journal of Midwifery, 2017.

[7] Zaki Masuma, Begum Wajeeha, and Roqaiya Mariyam. Efficacy of Amla (Emblica officinanis) and Shibe Yamani (Potash Alum) in the Management of Candida Vaginitis: A Randomized Standard Controlled Trial. International Journal of Reproduction, Contraception, Obstetrics, and Gynecology, 2016.

[8] Syahrir, N. A. UJI PERMUTASI EFEK SINERGIS BAHAN AKTIF TANAMAN OBAT BERBASISKAN JEJARING DENGAN PROTEIN TARGET. Thesis. Bogor: Sekolah Pascasarjana ITB Bogor, 2015.

[9] Pramanayudha Gilang, Khotimah Siti, and Rahmayanti Sari. Uji Aktivitas Antibakteri Senyawa Kitosan terhadap Neisseria gonorrhoeae yang diisolasi dari Pasien dengan Penyakit Infeksi Seksual secara In Vitro. Jurnal Cerebellum, 4(3), 2018.

[10] Jalestri, D. A., \& Taufikurohmah, T. UJI AKTIVITAS ANTIFUNGI NANOSILVER DALAM KRIM PAGI TERHADAP FUNGI Candida albicans. Unesa Journal of Chemistry, 2016, 128 - 136.

[11] Yanti Novi, Samingan, and Mudatsir. Uji Aktivitas Antifungi Ekstrak Etanol Gal Manjakani (Quercus infectoria). Jurnal Mahasiswa Pendidikan Biologi, 2016, 1 - 9.

[12] Malik, A., Marpaung, L., Simanjuntak, P., \& Nasution, P. AKTIVITAS SITOTOKSIK SENYAWA GOLONGAN FENOLIK DARI EKSTRAK DAUN SIRIH (Piper betle L.). Jurnal Fitofarmaka, 2017.

[13] Wijaya, W., Paramita, N., \& Susanti, N. Optimasi Metode Purifikasi Ekstrak Daun Sirih Hijau (Piper betle Linn) yang Memiliki Aktivitas Anbakteri terhadap Bakteri Propionibacterium Acnes. Jurnal Kimia Universitas Udayana, 2018, 36-42.

[14] Vifta Rissa Laila, Wansyah Muhammad Andri, and Hati Anita Kumala. Aktivitas Antibakteri Salep Ekstrak Etanol Daun Sirih Hijau (Piper betleL.) Terhadap Infeksi Bakteri Staphylococcus aureus. Kartika: Jurnal Ilmiah Farmasi, 5(2), 2017, 56-61. doi:10.26874/kjif. v5i2.117.

[15] Masyithah, N., \& Rijai, H. Aktivitas Antibakteri Ekstrak Daun Pacar (Lawsonia inermis L.). Jurnal Sains dan Kesehatan, 1(1), 2015.

[16] Aditya, M., \& Ariyanti, P. Manfaat Gambir (Uncaria gambir Roxb) sebagai Antioksidan. Majority, 2016.

[17] Cobra, L., Amini, H., \& Putri, A. Skirining Fitokimia Ekstrak Sokhletasi Rimpang Kunyit (Curcuma longa) dengan Pelarut Etanol 96\%. Jurnal Ilmiah Kesehatan Karya Putra Bangsa, 1(1), 2019, 12-17.

[18] Khariri, \& Puspandari, N. Proporsi Metode Pendekatan Sindrom dan Pewarnaan Gram dalam Diagnosis Infeksi Neisseria gonorrhoeae pada Wanita Penjaja Seks (WPS). Indonesian Journal of Medicine Science, 6(1), 2019.

[19] Mondal, K. SCREENING OF ANTIGONORRHOEAL ACTIVITY OF SOME MEDICINAL PLANTS IN NEPAL. International Journal of Pharma and Bio Science, 2(1), 2011. 
[20] Pangemanan Andrew, Fatimawali, and Budiarso Fona. Uji Daya Hambat Ekstrak Rimpang Kunyit (Curcuma longa) Terhadap Pertumbuhan Bakteri Staphylococcus aureus dan Pseudomonas sp. Jurnal e-Biomedik, 4(1), 2016.

[21] Fauzia, Wiyanto, and Lubis Sofyan. Pemeriksaan Potensi Tablet Ciprofloxacin yang Beredar di Apotek Kota Medan dengan Metode Pengenceran. Majalah Kedokteran Nusantara, 2005.

[22] Mutiawati, V. K. Pemeriksaan Mikrobiologi Pada Candida albicans. Jurnal Kedokteran Syiah Kuala, 16(1), 2016.

[23] Pelczar, M., \& Chan, E. Dasar - Dasar Mikrobiologi. Edisi ke-2. Jakarta: Penerbit Universitas Indonesia, 1988.

[24] Alfiah Raniyanti Rieska, Khotimah Siti, and Turnip Masnur. Efektivitas Ekstrak Metanol Daun Sembung Rambat (Mikania micrantha Kunth) Terhadap Pertumbuhan Jamur Candida albicans. Jurnal Protobiont, 2015.

[25] Kurniawati, A., Mashartini, A., \& Fauzia, I. Perbedaan khasiat anti jamur antara ekstrak etanol daun Kersen (Muntingia calabura L.) dengan nistatin terhadap pertumbuhan Candida albicans. Jurnal PDGI, 65(3), 2016, 74-77.

[26] Indrayati, S., \& Sari, R. I. Gambaran Candida albicans Pada bak Penampung Air di Toilet SDN 17 Batu Banyak Kabupaten Solok. Jurnal Kesehatan Perintis, 5(2), 2018.

[27] Sawitri, A. UJI BANDING EFEKTIVITAS KETOCONAZOLE 1\% DENGAN ZINC PYRITHIONE 1\% SECARA IN VITRO TERHADAP PERTUMBUHAN Pityrosporum ovale. Naskah Publikasi. Universitas Muhammadiyah Surakarta, 2011.

[28] Shino B, Peedikayil FC, Jaiprakash SR, Ahmed Bijapur G, Kottayi S, Jose D. Comparison of Antimicrobial Activity of Chlorhexidine, Coconut Oil, Probiotics, and Ketoconazole on Candida albicans Isolated in Children with Early Childhood Caries: An In Vitro Study. Scientifica (Cairo). 2016, doi:10.1155/2016/706158.

[29] Jalianto. UJI AKTIVITAS ANTIJAMUR EKSTRAK ETANOL BIJI BUAH LANGSAT (Lansium domesticum Corr.) TERHADAP JAMUR Candida albicans SECARA IN VITRO. Thesis Universitas Tanjung Pura, 2015. 